\title{
PENEGAKAN HUKUM TERHADAP RESIDIVIS TINDAK PIDANA PENCURIAN DALAM SISTEM PERADILAN PIDANA ANAK
}

\author{
Putu Eka Trisna Dewi \\ Magister Hukum Pascasarjana Universitas Ngurah Rai \\ Email: trisnadewi.ecak@gmail.com
}

\begin{abstract}
Behavioral deviations in children are things that are prone to occur because of the child's unstable psychology. Children who are in conflict with the law can be sentenced if they are proven to have committed a criminal act. The type of research in this paper is legal research using literature study and statute approach. The purpose of the imposition of punishment is not merely revenge, but to provide guidance and protection. This provision is also applied to the criminalization of children, even more attention is paid to criminalizing children, given the characteristics of children. Restrictions on the use of criminal law for children can be seen from the regulation of diversion against children in conflict with the law. However, for repetition or recidivist crimes, diversion against children cannot be done.
\end{abstract}

Keywords: law enforcement, recidivists, juvenile criminal justice system.

\begin{abstract}
Abstrak
Penyimpangan perilaku pada anak merupakan hal yang rentan terjadi karena jiwa labil anak. Anak yang berkonflik dengan hukum dapat dipidana apabila terbukti melakukan tindak pidana. Adapun jenis penelitian dalam tulisan ini adalah penelitian hukum dengan menggunakan studi kepustakaan dan pendekatan perundang-undangan. Bahwa tujuan dari penjatuhan pidana bukan semata-mata sebagai pembalasan dendam, tetapi untuk pemberian bimbingan dan pengayoman. Ketentuan ini juga diterapkan pada pemidanaan anak, bahkan pemidanaan terhadap anak lebih diperhatikan mengingat karakteristik anak. Pembatasan penggunaan hukum pidana bagi anak dapat dilihat dari pengaturan diversi terhadap anak yang berkonflik dengan hukum. Namun terhadap kejahatan pengulangan atau residivis maka diversi terhadap anak tidak dapat dilakukan.
\end{abstract}

Kata kunci : penegakan hukum, residivis, sistem peradilan pidana anak. 


\section{A. Pendahuluan}

Anak menurut Pasal 1 angka 1 Undang-undang Nomor 35 Tahun 2014 tentang Perubahan Atas Undangundang Nomor 23 Tahun 2002 tentang Perlindungan Anak adalah seseorang yang belum berusia 18 (delapan belas) tahun, termasuk anak yang masih dalam kandungan. Anak merupakan kelompok rentan dalam masyarakat yang perlu mendapatkan perlindungan.

Perlindungan anak juga diberikan kepada anak yang menjadi pelaku tindak pidana. Tujuan dan dasar pemikiran perlindungan hukum terhadap anak tidak dapat dilepaskan dari tujuan bagaimana mewujudkan kesejahteraan anak sebagai bagian integral dari mewujudkan kesejahteraan sosial secara menyeluruh. ${ }^{1}$

Anak yang berkonflik dengan hukum $^{2}$ dapat dipidana apabila terbukti melakukan tindak pidana. Tujuan dari

1 Arif Gosita, 2004, Masalah Perlindungan Anak (Kumpulan Karangan), BIP Kelompok Gramedia, Jakarta, hal. 43

2 Pasal 1 angka 3 Undang Undang Nomor 11 tahun 2012 tentang Sistem Peradilan Pidana Anak yaitu "Anak yang berkonflik dengan hukum yang selanjutnya disebut anak adalah anak yang telah berumur 12 (dua belas) tahun, tetapi belum berumur 18 (delapan belas) tahun yang diduga melakukan tindak pidana". penjatuhan pidana bukan semata-mata sebagai pembalasan dendam, tetapi untuk pemberian bimbingan dan pengayoman. Ketentuan ini juga diterapkan pada pemidanaan anak, bahkan pemidanaan terhadap anak lebih diperhatikan mengingat karakteristik anak. Pengayoman diberikan sekaligus kepada masyarakat dan kepada terpidana sendiri agar menjadi insaf dan dapat menjadi anggota masyarakat yang baik. Oleh karena itu, dapat dikatakan bahwa konsepsi baru fungsi pemidanaan bukan sebagai penjeraan belaka, tetapi juga sebagai upaya rehabilitasi dan reintegrasi sosial. Konsepsi itu di Indonesia disebut pemasyarakatan. ${ }^{3}$

Dalam penggunaan hukum pidana, diperlukan adanya prinsipprinsip pembatas (the limiting principles) sebagaimana yang dikemukakan oleh Nigel Walker mengemukakan yakni:

a. Janganlah hukum pidana digunakan semata-mata untuk tujuan pembalasan;

3 Muladi dan Barda Nawawi Arief, 1992, Bunga Rampai Hukum Pidana, Alumni, Bandung, hal. 3. 
b. Jangan menggunakan hukum pidana untuk memidana perbuatan yang tidak merugikan/ membahayakan;

c. Jangan menggunakan hukum pidana untuk mencapai suatu tujuan yang dapat dicapai secara lebih efektif dengan sarana-sarana lain yang lebih ringan;

d. Jangan menggunakan hukum pidana apabila kerugian/ bahaya yang timbul dari pidana lebih besar daripada kerugian/ bahaya dari perbuatan/ tindak pidana itu sendiri;

e. Larangan-larangan hukum pidana jangan mengandung sifat lebih berbahaya daripada perbuatan yang akan dicegah;

f. Hukum pidana jangan memuat larangan-larangan yang tidak mendapat dukungan kuat dari publik. $^{4}$

Pembatasan penggunaan hukum pidana bagi anak dapat dilihat dari pengaturan diversi terhadap anak yang berkonflik dengan hukum. Pasal 1

${ }^{4}$ Barda Nawawi Arief, 2002, Bunga Rampai Kebijakan Hukum Pidana, Citra Aditya Bakti, Bandung, hal. 48.
3

angka 7 Undang-undang Nomor 11 Tahun 2012 tentang Sistem Peradilan Pidana Anak mendefinisikan "Diversi adalah pengalihan penyelesaian perkara Anak dari proses peradilan pidana ke proses di luar peradilan pidana." Diversi menurut Pasal 7 ayat (1) Undang-undang Nomor 11 Tahun 2012 tentang Sistem Peradilan Pidana Anak wajib diupayakan diversi sejak pada tingkat penyidikan, penuntutan dan pemeriksaan perkara di sidang pengadilan negeri, sedangkan tindak pidana yang dapat diupayakan diversi menurut ayat (2) adalah:

1. tindak pidana yang ancaman pidananya di bawah 7 (tujuh) tahun; dan

2. bukan merupakan pengulangan tindak pidana.

Sehubungan dengan penerapan Pasal 7 Undang-undang Nomor 11 Tahun 2012 tentang Sistem Peradilan Pidana Anak, maka diversi wajib dilakukan apabila tindak pidana yang dilakukan diancam dengan pidana pidananya di bawah 7 (tujuh) tahun dan bukan merupakan pengulangan (residive). Kedua ketentuan tersebut 
wajib terpenuhi, sehingga apabila ada salah satu ketentuan yang tidak terpenuhi maka diversi tidak wajib dilakukan. Pidana penjara anak berbeda dengan orang dewasa, pidana penjara bagi Anak yang berkonflik dengan hukum, hal ini dapat dilihat pada Pasal 79 Undang-Undang Nomor 11 tahun 2012 tentang Sistem Peradilan Pidana Anak. Pidana pembatasan kebebasan hanya diberlakukan dalam hal tertentu saja, yakni dalam hal anak melakukan pidana berat atau tindak pidana yang disertai dengan kekerasan. Semangat perlindungan anak sangat menghindari jenis pemidanaan pembatasan kebebasan ini, jika memang anak harus dijatuhi pidana penjara maka pidana yang dijatuhkan paling lama $1 / 2$ (satu perdua) dari maksimum pidana penjara yang diancamkan terhadap orang dewasa.

Salah satu tindak pidana yang sering dilakukan oleh anak adalah tindak pidana pencurian sebagaimana yang diatur dalam Pasal 363 ayat (1) ke-4 dan ke-5 KUHP. Ketentuan Pasal 363 ayat (1) KUHP selengkapnya adalah sebagai berikut:
(1) Diancam dengan pidana penjara paling lama tujuh tahun:

a. pencurian ternak;

b. pencurian pada waktu ada kebakaran, letusan, banjir gempa bumi, atau gempa laut, gunung meletus, kapal karam, kapal terdampar, kecelakaan kereta api, huruhara, pemberontakan atau bahaya perang;

c. pencurian di waktu malam dalam sebuah rumah atau pekarangan tertutup yang ada rumahnya, yang dilakukan oleh orang yang ada di situ tidak diketahui atau tidak dikehendaki oleh yang berhak;

d. pencurian yang dilakukan oleh dua orang atau lebih:

e. pencurian yang untuk masuk ke tempat melakukan kejahatan, atau untuk sampai pada barang yang diambil, dilakukan dengan merusak, memotong atau memanjat, atau dengan memakai anak kunci palsu, perintah palsu atau pakaian jabatan palsu.

Tindak pidana pencurian melanggar Pasal 362 KUHP yang menyatakan "Barang siapa mengambil barang sesuatu, yang seluruhnya atau sebagian kepunyaan orang lain, dengan maksud untuk dimiliki secara melawan hukum, diancam karena pencurian, dengan pidana penjara paling lama lima tahun atau pidana denda paling banyak sembilan ratus rupiah." Tindak pidana 
atas pencurian tidak dapat dilakukan upaya diversi meskipun ancaman pidananya di bawah 7 tahun jika perbuatan tersebut merupakan pengulangan atau residive. Residivis merupakan salah satu dampak dari adanya ketidakberdayaan dalam diri seorang mantan narapidana anak untuk bersosialisasi kembali dalam masyarakat sebagai seorang remaja yang bertanggungjawab di tengah pandangan negatif masyarakat terhadap dirinya. Dalam konteks peradilan pidana anak, maka keberadaan residivis anak merupakan hal yang penting untuk menguji keberhasilan penjatuhan pidana. Dalam menangani perkara anak tentunya memerlukan kebijaksanaan hakim agar pidana yang dijatuhkan bukan merupakan pembalasan melainkan merupakan upaya agar anak tidak lagi mengulangi perbuatannya

\section{B. Metode Penelitian}

Adapun jenis penelitian dalam tulisan ini adalah penelitian yuridis dengan menggunakan pendekatan perundang-undangan. Dalam metode pendekatan perundang-undangan yang perlu dipahami adalah hierarki, dan asas-asas dalam peraturan perundang- undangan. $^{5}$ Pendekatan perundangundangan adalah pendekatan dengan menggunakan legislasi dan rugulasi. ${ }^{6}$ Menurut Terry Hutchinson terkait statute approach bahwa :

if you know the name of one Act, then you should be able to use this piece of information to locate :

- An updated version of the Act and any amendments through the annotations;

- Cases discussing the legislation through the annotations and encyclopaedias.

you will be using existing knowledge to link to further information relevant to your subject. ${ }^{7}$

\section{Pembahasan}

Dalam Penegakan hukum dalam dalam sistem Peradilan Pidana berkaitan dengan penanganan perkara anak tentu sebelumnya telah terjadi pelanggaran atau perbuatan pidana yang dilakukan oleh seorang anak sehingga mengakibatkan hukum yang dilanggar tersebut harus ditegakkan demi menjamin tujuan

5 Peter Mahmud Marzuki, 2016, Penelitian Hukum Edisi Revisi, Prenada Media Group, Jakarta, hal. 137

${ }^{6}$ Ibid.

7 Terry Hutchinson, 2002, Researching and Writing in Law, Lawbook Co., Australia, hal.35 
hukum yakni kepastian hukum, undang lainnya); dan tidak kemanfaatan, dan keadilan.

Bekerjanya hukum dalam rangka penegakan hukum terhadap perkara mengandung norma kabur (tidak memiliki arti yang multitafsir).

Berlanjut pada poin struktur pidana anak tentu didukung oleh hukum yang berkaitan dengan aparat beberapa faktor yang mempengaruhi, penegak hukum dan institusi penegak baik itu faktor penghambat maupun faktor pendorongnya. Keberadaan faktor-faktor tersebut tentu saja akan sangat berkaitan dengan sistem hukum itu sendiri yakni substansi, struktur, dan budaya hukumnya. Seperti halnya ketika berbicara mengenai penegakan hukum terhadap anak pelaku tindak pidana khususnya bagi pelaku residiv tentu faktor-faktor yang mempengaruhi sangatlah beragam.

Faktor yang mempengauhi berkaitan dengan eksistensi peraturan perundang-undangan yang mengatur mengenai penegakan hukum terhadap tindak pidana yang dilakukan oleh anak. Ketentuan tersebut hendaknya memenuhi persyaratan yang dapat dilaksanakan oleh aparat penegak hukum yakni tidak mengandung norma kosong (tidak ada aturan), tidak mengandung norma konflik (tidak saling bertentangan antara satu undang-undang dengan undanghukum yang akan melaksanakan tugas penegakan hukum terhadap pelaku tindak pidana anak yang berstatus residiv. Sejauh ini sebagaimana yang diatur dalam UU SPPA, penanganan perkara anak dilakukan oleh aparat penegak hukum yang khusus memahami masalah anak.

Sebagaimana yang diatur dalam Pasal 26 ayat (3) jis Pasal 41 ayat (2) jis 43 ayat (2) UU SPPA Penyidik, Penuntut Umum dan Hakim yang menangani perkara anak wajib memenuhi persyaratan sebagai berikut:

a. Telah berpengalaman sebagai penyidik; penuntut umum; dan hakim dalam peradilan umum;

b. Mempunyai minat, perhatian, dedikasi, dan memahami masalah Anak, dan

c. Telah mengikuti pelatihan teknis tentang peradilan Anak. 
Prosedur penanganan perkara pidana diatur dalam Kitab UndangUndang Hukum Pidana. Adapun prosedur tersebut terdiri dari beberapa tahapan, yakni:
a. Penyelidikan.
b. Penyidikan.
c. Penuntutan.
d. Pemeriksaan perkara di pengadilan.

e. Eksekusi putusan pengadilan.

Proses tersebut pada prinsipnya hampir sama dengan penanganan perkara orang dewasa pada umumnya. Namun ada beberapa kekhususan seperti :

a. Adanya penegak hukum yang khusus menangani tindak pidana anak seperti penyidik anak, penuntut umum anak, dan hakim anak, dengan syarat-syarat tertentu yang ditetapkan dalam UndangUndang SPPA.

b. Adanya pihak-pihak yang terkait dalam memberikan perlindungan terhadap anak yang berhadapan dengan hukum seperti pembimbing kemasyarakatan, tenaga kesejahteraan sosial, dan pekerja sosial profesional. c. Adanya perlindungan khusus dan hak khusus yang diberikan kepada anak sebagai pelaku tindak pidana yang mana berbeda dengan orang dewasa, seperti masa penahanan yang lebih singkat, dan maksimum ancaman pidana yakni $1 / 2$ (satu perdua) dari maksimum ancaman pidana bagi orang dewasa).

d. Karena pelaku anak berstatus sebagai residiv, maka berdasarkan ketentuan Pasal 7 ayat(2) UndangUndang Sistem Peradilan Pidana Anak dikecualikan untuk melakukan diversi.

Wujud dari suatu keadilan adalah dimana pelaksanaan hak dan kewajiban seimbang. Pelaksanaan hak dan kewajiban bagi anak yang melakukan tindak pidana perlu mendapat bantuan dan perlindungan agar seimbang dan manusiawi. Perlu kiranya digarisbawahi bahwa kewajiban bagi anak harus diperlakukan dengan situasi, kondisi mental, fisik, keadaan sosial, dan kemampuanya pada usia tertentu.

Pemeriksaan perkara anak dengan mekanisme sistem Peradilan Pidana Anak bagi pelaku residiv pada 
prosesnya melibatkan berbagai pihak sebagaimana disebutkan dalam Undang-Undang Sistem Peradilan Pidana Anak yakni Pembimbing Kemasyarakatan, Pekerja Profesional dan Tenaga Kesejahteraan Sosial. Pada prinsipnya tiga aspek inilah yang menjalankan beberapa tindakan kajian terhadap anak pelaku tindak pidana seperti melakukan penelitian kemasyarakatan, pembimbingan, pengawasan, pendampingan, dan pembinaan terhadap anak yang berkonflik dengan hukum atau anak pelaku tindak pidana. Tiga petugas inilah yang membantu aparat penegak hukum dalam melaksanakan proses peradilan pidana bagi anak yang berkonflik dengan hukum.

Tujuan dari adanya keterlibatan pihak-pihak tersebut adalah untuk memberikan hak-hak khusus bagi anak dan memberikan jaminan bagi anak yang sedang diperiksa dalam proses peradilan untuk diperlakukan dengan baik sesuai dengan ketentuan yang berlaku dan mendapatkan gambaran tentang asal muasal dan kondisi yang sesungguhnya dari anak pelaku tindak pidana tersebut.
Residive dalam Kamus Hukum diartikan sebagai ulangan kejahatan, dimana adanya suatu kejadian bahwa seseorang yang dahulu pernah dihukum karena melakukan suatu kejahatan, kembali melakukan suatu kejahatan. $^{8}$ Recidive terjadi apabila seseroang telah melakukan perbuatan pidana dan telah dijatuhi dengan putusan hakim dan pidana tersbut telah dijalankan, akan tetapi setelah selesai menjalani pidana dan dikembalikan ke masyarakat yang bersangkutan kembali melakukan perbuatan pidana. ${ }^{9}$ Untuk itu maka terhadap perkara recidive yang dilakukan oleh seorang anak dimana sebelumnya ia telah melakukan kejahatan dan telah diproses sesuai dengan hukum yang berlaku baik diselesaikan dengan cara diversi maupun dengan mekanisme peradilan pidana sesuai dengan Hukum Acara Peradilan Anak, anak yang bersangkutan kembali melakukan kejahatan setelah ia selesai menjalani masa hukuman berdasarkan kejahatannya terdahulu.

8 Subekti dan Tjitrosoedibjo, 2002, Kamus Hukum, Pradnya Paramita, Jakarta, hal. 94.

${ }^{9}$ I Made Widnyana, 2010, Asas-Asas Hukum Pidana, Fikahati Aneska, Jakarta, hal. 299. 
Adapun penegakan hukum terhadap anak pelaku tindak pidana pencurian dengan melakukan pengulangan tindak pidana, terhadap perkara anak yang berstatus sebagai recidive dilaksanakan menurut hukum acara Sistem Peradilan Pidana Anak sebagaimana diatur dalam Undang-Undang No. 11 Tahun 2012 tentang Sistem Peradilan Pidana Anak melalui serangkaian prosese yakni penyelidikan, penyidikan, penuntutan, dan persidangan untuk mendapatkan vonis atau putusan pengadilan. Dalam pelaksanaannya tidak dimungkinkan untuk diselesaikan secara diversi karena merupakan recidive karena bertentangan dengan syarat tindak pidana yang dapat diselesaikan secara diversi.

\section{Simpulan dan Saran}

Penegakan hukum terhadap residivis dalam sistem peradilan pidana anak yakni dengan menggunakan mekanisme sistem peradilan pidana anak melalui proses penyelidikan, penyidikan, penuntutan, pemeriksaan sidang pengadilan, lalu kemudian didapatkan vonis dan selanjutnya atas dasar putusan hakim tersebut anak yang menjadi residiv ini melaksanakan sanksinya baik berupa pidana maupun tindakan di instansi yang berwenang karena bagi anak yang melakukan tindak pidana pengulangan tidak memenuhi persyarat untuk diselesaikan dengan cara diversi.

\section{Daftar Pustaka}

\section{Buku}

Arief, Barda Nawawi, 2002, Bunga Rampai Kebijakan Hukum Pidana, Citra Aditya Bakti, Bandung

Gosita, Arif, 2004, Masalah Perlindungan Anak (Kumpulan Karangan), BIP Kelompok Gramedia, Jakarta

Hutchinson, Terry, 2002, Researching and Writing in Law, Lawbook Co., Australia

Marzuki, Peter Mahmud, 2016, Penelitian Hukum Edisi Revisi, Prenada Media Group, Jakarta

Muladi dan Barda Nawawi Arief, 1992, Bunga Rampai Hukum Pidana, Alumni, Bandung

Subekti dan Tjitrosoedibjo, 2002, Kamus Hukum, Pradnya Paramita, Jakarta

Widnyana, I Made, 2010, Asas-Asas Hukum Pidana, Fikahati Aneska, Jakarta 
Jurnal Hukum Saraswati (JHS) Volume. 03, Nomor 02, (2021)

ISSN (Cetak) : 2715-758X ISSN (Online): 2720-9555

DOI: https://doi.org/10.36733/jhshs.v2i2

https://e-journal.unmas.ac.id/index.php/JHS

10

Peraturan Perundang-Undangan

Kitab Undang-Undang Hukum Pidana

Undang-undang Nomor 35 Tahun 2014 tentang Perubahan Atas Undang-undang Nomor 23 Tahun 2002 tentang Perlindungan Anak.

Undang Undang Nomor 11 tahun 2012 tentang Sistem Peradilan Pidana Anak. 